\title{
THE ALLIANCE BETWEEN POLITICS AND PHILOSOPHY WITH REGARD TO THE THREATS OF THE XXI CENTURY
}

\begin{abstract}
The alliance between politics and philosophy pursues the object to change the world as public or social life. The life implies various degrees of quality, and suggests existence regarded as a desirable condition: life, liberty, and the pursuit of happiness. This is the main point of the Declaration of Independence (July 4, 1776). We have here a whole philosophy of politics referring to Plato's doctrine of the practical influence of philosophy on the state power to change the world (Plato, 1971, Rp. V 473d, VI 501e, VII 540d). The philosophy of politics holds life, liberty, and the pursuit of happiness to be unalienable rights and just so lays down the basic human rights as the principles of the political law, public law. The form of government which secures these rights is called democracy. America is no longer the ruler of her own spirit. In Armenia and Russia, there is instituted now timocracy, a form of government in which love of honor is the ruling principle (time honor + krateein to rule). There exist here public law apart from human rights. The task of the philosophy of politics is to secure democracy in the United States of America and to carry out the transition from timocracy to democracy in the Republic of Armenia and the Russian Federation.
\end{abstract}

Keywords: Philosophy of Politics, Plato, Hegel, Montesquieu, Jefferson, democracy, timocracy, information war, slander, dictatress of the world, the system of the threats, the change of the world.

Long time the well-known Plato's thesis about the mergence of power and philosophy with the purpose of deliverance of states from evils seemed to be Utopian. But today with regard to the threats of the XXI century just the alliance between politics and philosophy performs the duties connected with saving mankind from overhanging mortal danger.

For the space of the whole history of mankind, especially the last two centuries, the staunch ally of politics was not philosophy but war. In the attitude of mankind to war it is clearly observed two opposite methods of ap- proach which can be designated as the lines of Socrates and Glavkon. Both are the main personages of Plato's "Republic" discovering of war origin. The position of Socrates: war arises because of endless rapacity exceeding all bounds of need and impelling to seizing a part of a territory of a neighbouring country. It means evil. The war is the main source of private and public troubles when carrying on. Socrates appealed to beware of war. But it can be evoked by the necessity to protect the country, to repulse aggression. And then one will be forced to wage war. Thus wars may be 
unjust, predatory and just, ones of liberation. The position of Glavkon: a war is absolutely inevitable if we intend to have enough pastures and fields. It means good. This appraisal of war predominates in minds of politicians till present day.

An organic connection of war and politics was pointed out by a Prussian general and military theorist Carl von Clausewitz (17801831). He saw in war the continuation of the state politics with other means. "The war is not only a political act but a true instrument of politics, too, the continuation of political relations, their conducting with other means". The position of Clausewitz served as a stimulus for glorification of the old thesis about the inevitability of seizure of foreign territories and practically influenced on the organization of military campaigns of the German Empire and the Third Reich.

The conception of the organic connection between politics and war led to two world wars. The maintenance of their alliance in XXI century threatens to end with the World War III which can wipe off the earth the human race. Only urgent giving the baneful alliance up and the transition to the positions of the alliance between politics and philosophy can save the mankind from the world catastrophy. To paraphrase Plato one can rightfully assert that untill the state power and the philosophy will merge all together and untill in accordance with compulsory procedure will be removed those persons (and there are many of them) who now strive apart either for the power or for the philosophy, the genuine peaceful democratic states will not see the sunlight (Plato 1971: Rp. V 473 d). Thus the approaching World War III is the first real threat of the XXI century.
No less important is another threat: the war of information, the war of words. It came up to take the place of the ideological struggle, of the struggle of the ideas. The main instrument of the war of information is the slander directed to fan the conflicts between the states. "And all in the world can be slandered" (Plato, 1971, VI 500d). One becomes a slanderer by lack of education or by dilettantism. So Karl R. Popper in the tendentious work "The open Society and Its Enemies" (1945) represented Plato as a "totalitarian" thinker. This book slanders the mankind. It fabricates a fable that Plato under the name "the ideal state" wordily outlined a totalitarian regime which came true as the Third Reich and the USSR. Popper's arbitrary inventions in connection of "totalitarian" Plato are explained by his will to please the political hawks of the West straight after the end of the World War II. He has done all to close the access to the open society for the staunch ally of the USA and England. For the sake of this aim he has turned the philosophy into the servant of the aggressive politics. The words "totalitarian" and "authoritarian" were invented by Mussolini in 1925 as high - flown epithets of fascism. Lumping the USSR together with the Third Reich, Popper strived to discredit and shake the state of the democratic centralism.

Bertrand Russell's book "A History of Western Philosophy" (1945) slanders the mankind, too. He calls in question the existence of "wisdom" as the principle of aristocracy. Hence it follows: "The problem of finding a collection of "wise" men and leaving the government to them is thus an insoluble one. That is the ultimate reason for democracy" (Russell, 1945, p. 107). There is in this Rus- 
sell's conclusion a misunderstanding that must be cleared up. One can think that democracy excludes wisdom and wise men. They can be successfully found by showing their ability to aspire to legal power and philosophy simultaneously. Now the problem of finding a collection of wise men and leaving the government to them is on the agenda in the Republic of Armenia and Russian Federation. Russell erroneously considers Plato's guardians (suppliers of wise men) as "a class apart" to be enemies of the open society and is lumping together with them the Paraguayan Jesuits, ecclesiastics and the Russian revolutionists who were not a class apart: like Jacobins they went in advance to fall the first.

There is a simple and right solution of Russell's "insoluble problem": to exclude from the Constitutions of the Republic of Armenia and the Russian Federation all reference to the word "successively". This word was arbitrarily added by Yeltsin to the principal clause of the Amendment XXII (1951) to the Constitution of the United States: "No person shall be elected to the office of President more than twice successively". "Successively" must disappear. This word gives the former presidents the right to be elected more than twice and creates corrupt clans. Instead of such political wisdom the President of the Republic of Armenia declared coming transition to parliamentary form of government.

Popper and Russell happened to have found followers full of energy: Brzezinski, Friedrich, Linz, Sartori. The latter so characterized the method of the conduct of the information war: "The coinage of the apt words and their unceasing repetition. The whole trick is to start with the help of the apt words the slander. We must understand that this is highly effective method... I definitely do not like the war of words, but so is the reality" (Sartori, 1992, p. 469). The epithets of fascism - "totalitarian" and "authoritarian" - after the more precise definition of their content have become the apt words directed against the USSR, and now already against Russia, too. And to ensure their unceasing repetition, the slanderers have inserted them in a "new" (after Montesquieu) classification of the forms of government: democracy, authoritarianism, totalitarianism. The crowds of philistines, various "learned" gentlemen and officials by means of the frequent repetition of judgements of the type "The USSR is a totalitarian empire", "Russia is an authoritarian state" turned them into most dangerous prejudices threatening the existence of the mankind. That is what brought the transformation of the philosophy into the servant of the politics. The place of the truth has occupied the slander, false accusation.

The western slanderers suggested to ignorant Khrushchev an idea of Stalin's cult to equate him with Hitler's cult. This idea appeared to be attractive because it allowed Khrushchev with the help of the apt words "Stalin's personality cult" to depreciate the merits of his late lord and to exalt himself. The slander against Stalin led to the split of the party top and the whole country. The merits of Stalin in the Great Patriotic and the World War II were recognized by the country and mankind. Even the Americans and Englishmen did great honor to him when he has arrived to Potsdam. The argument about Stalin's merits before the Motherland still is not ceasing.

The traitors of the proletarian thought suddenly felt themselves liberals. In Russia 
there exist always two kinds of liberals: liberals in the sphere of morals and liberals of business sphere. The first mentioned are grouping round the parliament, the latter round the president endowed with almost dictatorial powers. In 1993 the parliament was shot down from cannons. After that followed two-day bloody citizen war. Then both of them came to an agreement. The first such a political and social upheaval came over in Ancient Greece, when between the aristocratic, attracting to morals, and the self-interested parts of the ruling top arose hostility. "Using the force and rivaling with each other, they finally came to something average: agreed to establish private property for the land and houses distributing them among themselves, and those whom they till this time protected as their free friends and bread-winners, decided to turn into slaves, making out of them rural workers and servants, but themselves were engaged in the military matter and guard service" (Plato, 1971, VIII 547c). As we see, the new incomers are ambitious men having established the private property only for themselves and having turned the free people into the service for themselves, too. A government which is founded on ambition is known under the name "timocracy". One may think that here Plato has described the transition from the collapsed Workers' and Peasants' republic to Russia of Yeltsin and Putin in which the basic human rights exist only de jure, on paper. But de facto the ignorant rulers usurped the rights to freedom, security and property, supposing that those are the rights of the state. For the common people only the right to resistance against the oppression is retained. In Russia privatization is constantly realized in the criminal form of "prikhvatization" (to carry out theft) followed by president's decree about an amnesty of capitals.

The greatest of all these evils is developing today before our eyes: the threat of becoming of the USA the dictator of the world. "America goes not abroad in search of monsters to destroy.... She might become the dictatress of the world; she would no longer be the ruler of her own spirit". Just so John Quincy Adams, sixth president of the United States, son of John Adams, second president of the United States, determined the place of America in the world. The warning prophecy, contained in Adams' words, have come true on that days when America went to Near East to destroy the "monster" Saddam Hussein. At that time she made the first step to become the dictatress of the world. True, the question is of America in the person of the conservative political coalition which at that moment supported the republicans as the party of the majority in the national politics. The spirit of freedom and democracy usual for America began to disappear because of violating the great ideology of American founding fathers. After the liberalization and (as a result) destruction of the Soviet Union which in the opinion of the American conservatives and European liberals was the "empire of evil" remained else the countries of the "axis of evil" representing rather the ready booty than a real threat for the West. In such favourable conditions the American expansion has acquired extremely aggressive character. Among the factors of American expansion (ideology, economics, military strategy, internal politics) first and foremost swiftly went out the military strategy. This is the strategy of the highly precise lightning stroke. The factor of individual possessing the powerful 
arsenal of highly precise usual weapons the first men of violence of the XXI century considered to be a "source" of the right of the United States to search in countries of the "axis of evil" banned weapons, to overthrow despotic regimes existing there and to establish democracy. What despotism is in question?

The eastern despotism is being considered. In contrast to the western despotism it never becomes the totalitarian tyranny. It is very important here to note that the Islam imposes a certain bridle on the eastern despotism. According to Hegel who belonged to the generation of John Quincy Adams, the most gifted and educated president of the United States, Islam is in the true sense of the word the religion of the elevated. Concerning the inhabitants of the Near East, especially the Arabs, the best minds of the XIX and XX centuries kept to the idea that this people in its fit to the united god is indifferent to any calamity, generously sacrifice its life and its material wealth. The Islam is abolishing any caste system and spreading the spirit of individual freedom. The true despotism has no place in the states of the Near East. The regime of Saddam Hussein was not a special exception to the general rule.

An acknowledged threat of the XXI century is the international terrorism. Partly it has arisen as a protest against the expansion of America which has become the dictatress of the world. But partly the cause of its origin became the religious fanaticism. Concerning the latter Montesquieu noticed: "The evil rooted in the idea that the man is obliged to take revenge for the deity". In consequence of the abuse of the deity's name the concept of the sacrilege became boundless and served as the occasion to most brutal and unjust punishments generously scattered by terrorists. But one can rightfully point out the idleness of their fanaticism. The terrorists joined the principle of fear, horror to the principle of virtue. The virtue became fearful as in the epoch of the French revolution. Meanwhile it is necessary here tolerance, not fear. Why? The question of tolerance is the fundamental religious question. The sight of this is completely lost by the religious fanatics. Because of it liberals seized the opportunity of declaring tolerance the basic value of Europe. With the help of compliance and mildness the terrorists would achieve many more results if they indeed want to turn virtue into the conviction of a modern man. Then the terror will go down, too. It must be outdated. It is impossible to fight with this evil only by means of physical elimination of death-terrorists and of unceasing repeating the apt words "the terrorist organization banned in Russia". Montesquieu pointed out the idleness of this method: "The men who wait in the future life for the certain reward escape the hands of the legislator; they despise the death too much". The governments are obliged to observe strictly tolerance concerning the world outlook and punishment of the religious fanatics. It must be put a veto on the obscene caricatures insulting under different pretexts the memory of the great prophet.

The unquestionable threat of the XXI century is the approaching of NATO to the frontiers of Russia. This is a proud country and great nuclear power. It is dangerous to try its patience by unreasonable sanctions and permanent intimidation. The people of Russia perfectly remembers perfidious assault upon the USSR by the Nazi Germany on the 22nd 
of June 1941, terrible defeats and the Great Victory. If the expansion of NATO to East leads to a war then it is not excepted that the Russian timocracy will prevail over the American democracy. As the classical lesson can serve the Peloponnesian War in which the timocratic Sparta prevailed over the democratic Athens.

Thus the system of threats of the XXI century can be presented in the form of a pyramid with the summit "America the dictatress of the world" and the sides representing the ascent to the summit according to degree of strengthening of the threats and the descent according to degree of their weakening.

It remains to be seen (and this is important fundamental question): how are the threats of the XXI century to be fought? First of all it must be put an end to the slanderous war of information. Unexpectedly Germany has given the lead in the cause of abandoning the notorious war of words. On the 2 nd of June 2016 the Bundestag recognized the fact of the Genocide of the Armenians after 101 years from the time of its committing. By force of the magical figure 100 the German negationists of the Genocide of the year 1915 were put to silence. This is a whole upheaval in the international relations. For tens of years the war of information was under way against the Armenian people which has suffered the deportation into the other world. The Genocide was deliberately called a mass murder. Through the malicious nonrecognition of the Genocide of the year 1915 the United States and other states are pecking at Armenia and do not let it rise. The active attitude of the German parliamentarians of Turkish origin deserves approval. The German people is tired of the war of words representing a prod- uct of the devil calling the youth "to stick in polemics to words", not to ideas, but words, not to struggle of ideas, but to war of words. As far as the morals of the governments of Israel and Turkey are concerned, one can think that they are exactly confused by the devil. These politicians cannot comprehend that in the cause of the recognition of the Armenian holocaust the evidence of Sarah Aronson (1890-1917) outweighs mountains of archive documents. She was tortured to death by Turks, and it became the prelude of the Jewish holocaust. Sarah's death shows the inner tie of both holocausts.

Paraphrasing Hegel one can by right assert that the state power and politics, however they try to reason without addressing to philosophy, they can possess without it neither life nor spirit nor truth. Meanwhile the war of information, the war of words turned philosophy into a servant of politics. It only has brought nearer the world catastrophe. Under the circumstances extremely actual has become the slogan "No philosophy, no politics, no politics, no philosophy". Only the merging of the state power and the philosophy, the powerful alliance between them can cope with the oncoming terrible events. Instead of yielding in the field of international relations to wholly human spirit, the governments are only talking profusely about the national interests. They appreciate the national interests above the great ideas of mankind (truth, freedom, justice, humanity, progress). Let us on that score listen to Montesquieu: "If I knew something advantageous for my family and disadvantageous for fatherland, I should try to forget about it, and if I knew something advantageous for my fatherland and harmful for Europe and for mankind, I should consider it 
criminal". Thus to show off a long list of evils produced by the "ideology" and to glorify the national interests, this is only a bad profuse talk against the great ideas of mankind.

The system of the international relations turned out now thus that in Europe one of the states after 20 years of America's service cast off its fetters and began to speak about equality. This is Russia. All powers of the so-called West scold it and do not let it rise. Then England. It leaves the European Union by force of definite civilizational processes. The western civilization has two faces: the Anglo-Saxon and the eurocontinental one. England returns into the lap of the Anglo-Saxon civilization. This only will widen the borders of the eurocontinental civilization a part of which before the collapse of the USSR was Russia. Huntington is right insisting that "when Russians ceased to conduct themselves as Marxists and began to conduct themselves as Russians the gap between them and the West increased". It is clear that this gap must be removed. There is no need to become Marxists again. One simply must not be ashamed of Marxism and run down the history of the USSR to please Brzezinski. Then very soon Russia will occupy England's place in the union of the peoples of continental Europe. Russia is not "Orthodox", China is not "Sino"-civilization, as insists Huntington. The Chinese conduct themselves as Marxists, therefore the gap between them and West is impetuously reducing.

In the nearest perspective two alliances will countervail: on the one hand the USA and England, on the other hand Russia and China. The approximate parity of their forces will ensure the balance in the international relations. The war of information on the part of Anglo-Saxons will be continued, but it will lose its blaze as the war of words will be brought to a stop by the fight of ideas.

\section{REFERENCES}

Adams, J.Q. (1991). Expansion, Continental and Overseas. The Reader's Companion to American History. (E. Foner, \& J. Garraty, Eds.), Boston.

Aristotele. (1971) Politik, hg. v. Carl Andresen, Olof Gigon. 2., durchgesehene und um einen Kommentar erweiterte Auflage, Artemis-Verlag, Zürich, Stuttgart.

Clausewitz, C. von (1957) Vom Kriege. Berlin.

Grundlinien der Philosophie des Rechts (1831). Suhrkamp, Frankfurt am Main, 1970

Hegel, G.W.F. (1980). Phänomenologie des Geistes, hg. v. Wolfgang Bonsiepen u. Reinhard Heede. (Gesammelte Werke, Bd. 9) Meiner, Hamburg.

Huntington, S.P. (1996). The Clash of Civilizations and the Remaking of World Order.

Jefferson, T. (1776). Declaration of Independence, July 4.

Montesquieu, C.L. de (1951). L'esprit des lois. Dt. Vom Geist der Gesetze, 2 Bde. H. Laupp'sche Buchhandlung, Tübingen.

Platon. (1970). Werke, hg. v. Gunther Eigler. Wissenschaftliche Buchgesellschaft, Darmstadt. Darin: Der Staatsmann (Bd 6).

Platon. (1971). Werke, hg. v. Gunther Eigler. Wissenschaftliche Buchgesellschaft, Darmstadt. Darin: Der Staat (Bd. 4). 
Poghosyan, W. (2013). The Forms of Government and the State Morals in the Contemporary World. Wisdom №1. Yerevan: Tigran Mets Publishing House.

Popper, K.R. (1945). The Open Society and its Enemies. rev. Aufl. Routledge and Kegan Paul, London, 1952.
Russell, B. (1945). A History of Western Philosophy, N.Y.: Simon and Schuster 1964.

Sartori, G. (1987). Demokratietheorie. Darmstadt: Wissenschaftliche Buchgesellschaft, 1992. 